Lyric Address in Dutch Literature, 1250-1800 



\title{
Lyric Address in Dutch Literature, 1250-1800
}

\author{
Edited by \\ Cornelis van der Haven and Jürgen Pieters
}


This publication was made possible through financial support of the FWO-funded research community ‘Goliath’.

Unless indicated otherwise, all poems in this book are translated by Myra Scholz.

Cover image: Simon Vouet, Parnassus or Apollo and the Muses, c. 1640, Szépművészeti Múzeum / Museum of Fine Arts, Budapest

Photograph: Dénes Józsa

Cover design: Coördesign, Leiden

Typesetting: Crius Group, Hulshout

Amsterdam University Press English-language titles are distributed in the US and Canada by the University of Chicago Press.

ISBN $\quad 9789462982284$

e-ISBN 9789048532186 (pdf)

DOI $\quad 10.5117 / 9789462982284$

NUR $\quad 621$

(C) Cornelis van der Haven \& Jürgen Pieters / Amsterdam University Press B.V., Amsterdam 2018

All rights reserved. Without limiting the rights under copyright reserved above, no part of this book may be reproduced, stored in or introduced into a retrieval system, or transmitted, in any form or by any means (electronic, mechanical, photocopying, recording or otherwise) without the written permission of both the copyright owner and the author of the book. 